\title{
CLINICAL EFFICIENCY OF CLARITHROMYCIN-MB IN COMPLEX THERAPY OF PATIENTS WITH NON-HOSPITAL PNEUMONIA
}

\author{
Liadova Tetiana, Volobuieva Olha, Nartov Pavlo, Malanchuk Svitlana, Hololobova Olesia, Kozlov \\ Oleksandr, Kasian Natalia, Gamilovska Alla, Shander Tetiana
}

Mail for correspondence: o.volobyeva@karazin.ua

Summary: The problem of rational antibiotic therapy of pneumonia is among the most relevant in modern medicine. The aim of the study was to evaluate the clinical efficacy and therapeutic tolerance of parenteral application of clarithromycin in the treatment of patients with non-hospital pneumonia (NHP). Materials and methods. We observed 20 patients: 12 men - (60\%), 8 women-(40\%), the average age of patients was $46.1 \pm 17.6$ years. All patients showed clinical symptoms of severe infection of the lower respiratory tract. In $75.0 \%$ (15 patients) bilateral lung damage was noted, in 27\% (5 patients) - unilateral lung tissue damage. Hemoptysis was observed in $4(20 \%)$ patients. Clarithromycin-MB was included in complex therapy (detoxification, mucolytic drugs, multivitamins, and metabolices) for 6 patients with NHP after 3 days of ineffective starting therapy, 14 patients with emergency received clarithromycin-MB immediately after admission to the hospital. The drug was administered by intravenous drip for 60 minutes at a dose of $500 \mathrm{mg}$ 2 times a day for 7-10 days. Result. The analysis of the obtained results of clarithromycin-MB therapy showed that clinical success was achieved in all patients. The positive dynamics of clinical indicators was noted already on the 3rd day from the beginning of antibiotic therapy with clarithromycin-MB, which was expressed in a decrease in body temperature until the 7th day of treatment, and in almost all patients the temperature returned to normal and only in 1 (5\%) patient remained subfebrile. Also, during this period, patients noted a decrease in pain syndrome as well as signs of intoxication. According to the data of X-ray studies on the 10th day of therapy, 6 (30\%) patients showed complete disappearance of infiltrative changes in the lungs, in 14 (70\%) patients - a significant decrease in their severity. On the 15-24th (average $15.3 \pm 1.2)$ days after the start of therapy signs of inflammatory infiltration in the lungs leveled off on the 15-24th in all patients. Conclusion. Clarithromycin-MB has good therapeutic tolerance, allows maintaining the required concentration in the focus of inflammation because of dosage regimen also affects the clinical and bacteriological effectiveness of therapy.

Key words: non-hospital pneumonia, macrolides, clarithromycin, respiratory failure, laboratory diagnostics

\section{Information about author}

Liadova Tetiana, MD, PhD, Full Prof.

Head of Department of general and clinical immunology and allergology, school of medicine, N.V. Karazin Kharkiv National University, Svobody sq., 6, Kharkiv, Ukraine, 61022

e-mail: t.lyadova@karazin.ua

https://orcid.org/0000-0002-5892-2599

Volobuieva Olha, MD, PhD, Assoc.

Prof., Department of general and clinical immunology and allergology, school of medicine N.V. Karazin Kharkiv National University, Svobody sq., 6, Kharkiv, Ukraine, 61022

e-mail: o.volobyeva@karazin.ua https://orcid.org/0000-0002-5569-1748

Nartov Pavlo, MD, PhD, Full Prof., Department of general and clinical immunology and allergology, school of medicine, N.V. Karazin Kharkiv National University, Svobody sq., 6, Kharkiv, Ukraine, 61022

e-mail:okia.mf@karazin.ua
Malanchuk Svitlana, MD, PhD, Assoc.

Prof., Department of general and clinical immunology and allergology, school of medicine, N.V. Karazin Kharkiv National University, Svobody sq., 6, Kharkiv, Ukraine ,61022

e-mail: s.malanchuk@karazin.ua https://orcid.org/0000-0002-9376-3693 Hololobova Olesia, MD, PhD, Assoc. Prof., Department of general and clinical immunology and allergology, school of medicine N.V. Karazin Kharkiv National University

Svobody sq., 6, Kharkiv, Ukraine, 61022 e-mail: ololesya@ukr.net

https://orcid.org/0000-0002-1713-2988

Kozlov Oleksandr, MD, PhD, Assoc.

Prof., Department of general and clinical immunology and allergology, school of medicine, N.V. Karazin Kharkiv National University, Svobody sq., 6, Kharkiv, Ukraine, 61022

e-mail: kozlov@karazin.ua

https://orcid.org/0000-0003-0320-1505
Kasian Natalia, MD, Assistant of Department of general and clinical immunology and allergology, school of medicine, N.V. Karazin Kharkiv National University, Svobody sq., 6, Kharkiv, Ukraine, 61022

e-mail:n.kasyan@karazin.ua https://orcid.org/0000-0003-4267-7995

Gamilovska Alla, MD, assistant of Department of general and clinical immunology and allergology, school of medicine N.V. Karazin Kharkiv National University, Svobody sq., 6, Kharkiv, Ukraine, 61022

e-mail: gamilovska@karazin.ua https://orcid.org/0000-0002-6652-0952

Shander Tetiana, MD, assistant of Department of general and clinical immunology and allergology, school of medicine, N.V. Karazin Kharkiv National University, Svobody sq., 6, Kharkiv, Ukraine, 61022

e-mail: tanyashander@gmail.com 
The problem of rational antibiotic therapy of pneumonia is among the most relevant in modern medicine. Despite the powerful arsenal of antibacterial agents, we come across an increase in the incidence of pneumonia and its complication [1]. Establishing of this diagnosis is an unconditional indication for the appointment of antibacterial drugs [2,3]. The multidrug resistance of microorganisms, formed as a result of irrational use of antimicrobial drugs, has recently become increasingly important $[4,5]$. A large number of factors have been to date identified, which determined the optimal quality of antimicrobial therapy: the maximum efficiency with the minimal toxicity of drugs should be combined with their correct cost. The results of morbidity control centers studies show that the increase in overall morbidity and mortality is to a large extent due to antibiotic resistance, which leads to a significant increase in the risk of mortality and duration of hospitalization $[4,5]$.

It is known that in the early 90's the concept of evidence-based medicine entered clinical practice, when the treatment tactics and pharmacological drug choice are based on the results of controlled studies, rather than on the subjective experience of the doctor. Within that framework, it is impossible to prescribe antibacterial therapy adequately without monitoring the resistance of microorganisms in a particular department of an infectious disease hospital.

Three classes of antimicrobial drugs exist in modern infectious practice among the most common antibacterial drugs: $\beta$-lactams, fluoroquinolones and macrolides. Macrolides are essential only in the treatment of respiratory and ENT infections, mycobacteriosis, chlamydial and uroplasma infection, soft tissues and skin, as well as pelvic infections.

Modern classification of macrolides includes 3 groups, which are formed depending on the number of carbon atoms in the lactone ring:

I. 14- nomial: erythromycin, clarithromycin, roxithromycin;

II. 15-nomial: (azolides): azithromycin;

III. 16- nomial: spiramycin, josamycin, medicamycin, medicamycin acetate.

The mechanism of action of macrolides is in their ability to contact with $50 \mathrm{~S}$ ribosome unit, which leads to microorganism's protein synthesis inhibition. Accumulating in phagocytes in high concentrations, macrolides contribute to the intracellular death of the pathological agent. Besides, macrolides stimulate mechanisms of nonspecific defense of the organism $[6,7,8]$. The action of this group of antibiotics is usually bacteriostatic, but in high concentrations, they may have bactericidal properties. Such effect is manifested by macrolides against Haemophilus influenzae (H. influenzae), Streptococcus pyogenes (S. pyogenes), Moraxella catarrhalis (M. catarrhalis), Streptococcus agalactiae (S. agalactiae), Neisseria gonorrhoeae (N. gonorrhoeae), Streptococcus pneumonia (S. pneumonia) [6].

Clarithromycin is a representative group of macrolides, approved for use in 1991. The drug is available in two forms: tablets for oral use and powder for solution for infusion. Structurally, clarithromycin is a semi-synthetic drug, its antimicrobial action is due to the ability to block protein synthesis by a microbial cell. At the same time, its immunomodulatory and antiinflammatory effects occurs due to increasing the phagocytes ability to chemotaxis. Clarithromycin increases the phagocytic activity of macrophages and neutrophils [9]. Synergistic bactericidal effects of blood serum complement and clarithromycin were revealed. Presence of clarithromycin increases the T-killers activity, which is probably important in the treatment of patients with bacterial infections complicated by viral super-infections [10]. The antiinflammatory effect is due to a decrease in the activity of cyclooxygenase and lipoxygenase cells. It has become recently known about the inhibition of the mediator chain of proinflammatory cytokines, such as interleukin-6, tumor necrosis factor- $\alpha$ [11], which significantly increased the efficiency of treatment in severe forms of ventilator-associated pneumonia [12]. In patients with respiratory infections, clarithromycin inhibits the formation of sputum and improves its rheological properties [13]. All this became the basis for the use of clarithromycin as an etiotropic drug for the treatment of patients with non-hospital pneumonia (NHP). 
The aim of the study was to evaluate clinical efficiency and therapeutic tolerability of clarithromycin in a parenteral use form for the treatment of patients with non-hospital pneumonia.

Materials and methods. There were 20 patients under our supervision in whom the signs of NHP were radiologically confirmed, which required hospitalization. This study included 12 men $-(60 \%), 8$ women $-(40 \%)$, the average age of patients was $46.1 \pm 17.6$ years. According to the order of the Ministry of Health of Ukraine №128 from 19.03.2007 it is recommended to divide the NHP into 4 groups depending on the severity of the process [2]. All examined patients belonged to the 4th group of patients with severe NHP course and required hospitalization in the intensive care unit. Clinical examination, chest radiography, electrocardiography, clinical and biochemical blood tests, urine and sputum tests were performed before the therapy, after 3 days and after 10 days of therapy. At the same time bacteriological examination of sputum and identification of microorganisms from hemoculture with an assessment of their sensitivity to antibacterial drugs (disc-diffusion method) were performed. Serological test was performed before treatment to detect $\mathrm{Cl}$. pneumoniae, $\mathrm{Cl}$. psittaci, Mycoplasma pneumoniae, Legionella pneumophila, Coxiella burnetii. Morning sputum obtained with appropriate preparation was used for microbiological examination. In order to determine the suitability of the sputum sample for culture, bacterioscopy of Gram-stained smears was performed. The material was considered high quality in the presence of $>25$ polymorphonuclear leukocytes and $<10$ epithelial cells in the field of view at low magnification $(\times 100)-\mathrm{V}$ and VI classes by P. R. Murray, J. A. Washington. According to the results of bacteriological research, the causative agent of NHP was isolated in $84.8 \%$ of patients. The main pathogens were $\mathrm{S}$. pneumoniae, $\mathrm{H}$. influenzae and Kl. pneumoniae. All isolated strains of $\mathrm{S}$. pneumoniae remained highly sensitive to protected aminopenicillins, cephalosporins of the III generation and clarithromycin. Isolated strains of Haemophilus influenzae were sensitive to aminopenicillins, clarithromycin, azithromycin and ceftriaxone. Strains of K. pneumoniae that are not sensitive to clarithromycin and azithromycin were not detected.

In view of the isolation and identification of the NHP causative agent usually requires at least 3 days, the initial antibacterial therapy was performed with drugs of different groups: cefepime, meropenem, augmentin, levofloxacin, ceftriaxone. All patients had clinical symptoms of severe infectious lesions of the lower respiratory tract, namely: temperature, shortness of breath, cough, chest pain, severe signs of intoxication (table 1).

Table 1. Clinical manifestations of non-hospital pneumonia before the beginning of clarithromycin-MB therapy $(n=20)$

\begin{tabular}{|c|c|c|}
\hline Symptoms of the disease & Abs. & \% \\
\hline Cough & 20 & 100 \\
\hline Symptoms of intoxication & 20 & 100 \\
\hline Temperature & 20 & 100 \\
\hline Shortness of breath & 15 & 75,0 \\
\hline Pleural pain & 9 & 45,0 \\
\hline Hemoptysis & 4 & 20,0 \\
\hline Bronchial breathing & 4 & 20,0 \\
\hline Impaired breathing & 18 & 90,0 \\
\hline Presence of sputum & 17 & 85,0 \\
\hline Wheezing, crepitus, pleural rub & 16 & 80,0 \\
\hline Unilateral lesion & 5 & 25,0 \\
\hline Bilateral lesion & 15 & 75,0 \\
\hline
\end{tabular}


In the majority of patients percussion and auscultatory signs dominated in the clinic of NHP, which indicated pathology of the lung tissue. In $75.0 \%$ of cases (15 patients) bilateral lung lesion was noted. It should be mentioned that at unilateral lesion of pulmonary fabric changes were found on the right - at $25 \%$ of cases (5 patients). Hemoptysis was observed in $4(20 \%)$ patients. All patients had leukocytosis with a shift of the leukocyte formula to the left. Anemia was detected in $4(20 \%)$ patients with NHP. Elevated ESR was observed in $85 \%$ of cases (17 patients).

Clarithromycin-MB was included in the complex therapy (detoxification, mucolytic drugs, multivitamins, metabolites) in 6 patients with NHP after 3 days of ineffective initial therapy, 14 patients with NHP received clarithromycin-MB immediately after admission to the hospital. The drug was administered intravenously drip for 60 minutes at a dose of $500 \mathrm{mg} 2$ times a day for 7-10 days.

The clinical efficiency of antibacterial therapy was assessed by the dynamics of the inflammatory process activity in the lungs. For this purpose, the following clinical and laboratory parameters characterizing the activity of the inflammatory process (temperature reaction, tachycardia, respiratory rate, leukocytosis, number of immature granulocytes, changes in ESR) as well as the severity of pain, radiological changes in the lungs were assessed. The dynamics of clinical and laboratory signs were taken into account before treatment, during treatment (3-5 days of therapy) and on the10th day after taking the drug. Radiological efficiency was also assessed at the end of therapy.

The clinical efficacy of clarithromycin-MB antibacterial therapy was assessed as "good" if there was an improvement in the subjective and objective condition of patients, reduction and normalization of body temperature, disappearance of pain syndrome, a steady tendency to normalize laboratory parameters on the 3rd day of therapy The efficiency of antibacterial therapy was assessed as "satisfactory", if there was an unstable improvement in laboratory parameters and persisted sub-febrile condition on the background of subjective improvement of patients. "Unsatisfactory" results of the treatment without the improvement of the patients' condition and absence of the tendency to normalize laboratory parameters were not noticed in our observations.

The results of radiological data of the chest were interpreted in the following way: "improvement" - with positive dynamics or complete disappearance of radiological signs of NHP, "no changes" - absence of improvement compared to the original radiological picture.

Statistical processing of the obtained research results was performed using the program STATISTIKA for Windows (Stat Soft Inc, USA) on a computer with a Pentium II Celeron 850 PPGA processor.

Research results. Analysis of the received results of clarithromycin-MB therapy demonstrated that clinical success was achieved in all patients (fig.1).

Positive dynamics of clinical indicators was observed on the 3rd day from the beginning of clarithromycin-MB antibacterial therapy, which was expressed in lowering of body temperature, almost all patients had normalized temperature by the 7 th day of treatment and only in $1(5 \%)$ patient the sub-febrile condition was kept. In this period patients also noted a decrease in pain syndrome, they had reduced signs of intoxication (Fig. 1). Analyzing laboratory parameters, we reliably found that the ESR acceleration rate decreased on the average from $26.4 \pm 2.9$ to $7.3 \pm 0.8 \mathrm{~mm} / \mathrm{h}$ (p $<0.05$ ); the number of leukocytes - from $12.5 \pm 1.5$ $\mathrm{x} 109 / 1$ to $6.2 \pm 0.5 \times 109 / 1(\mathrm{p}<0.05)$ up to the 10th-12th day of therapy 


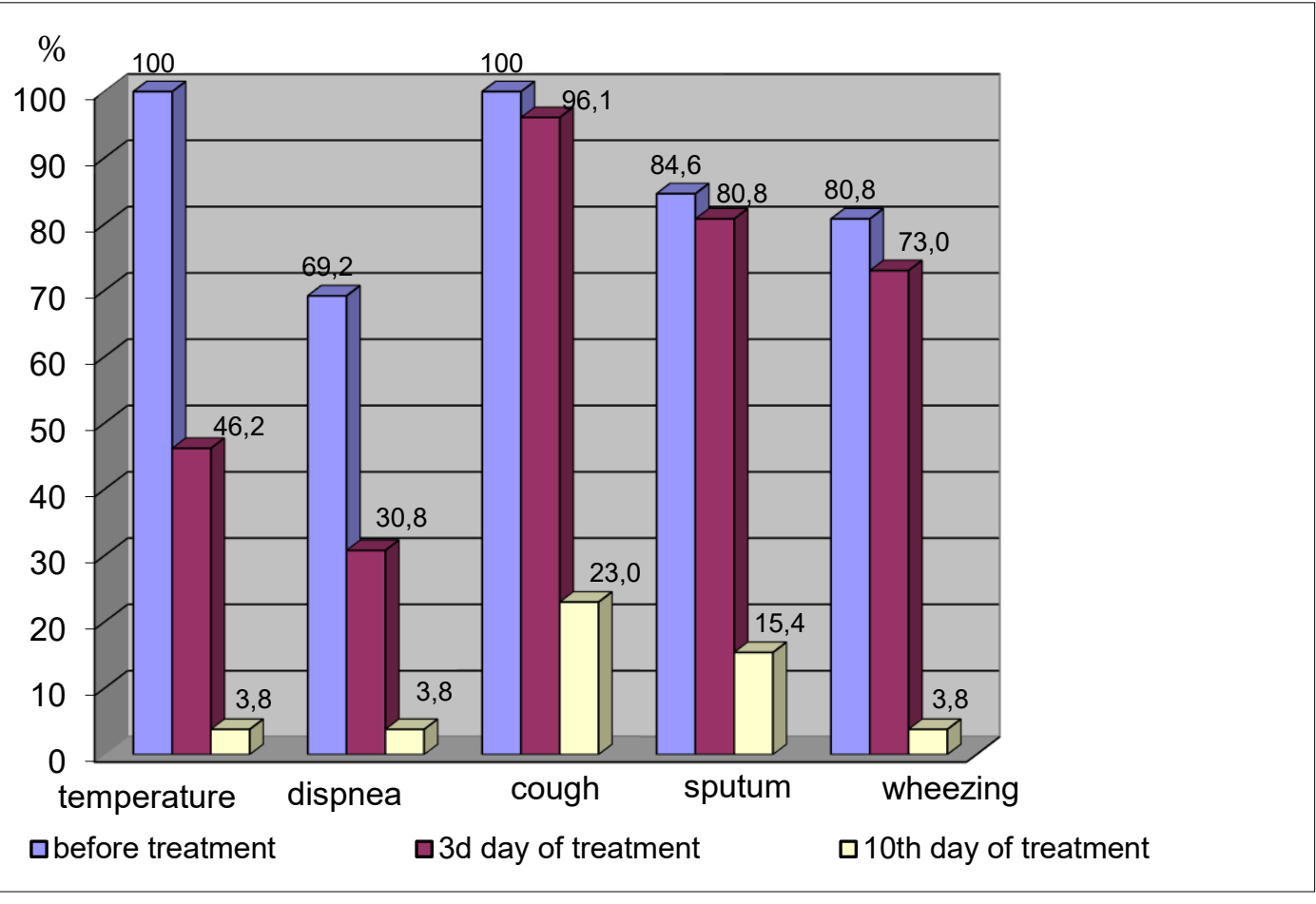

Fig. 1. Dynamics of main clinical symptoms in patients with NHP with clarithromycin therapy

According to radiological studies in $6(30 \%)$ patients there was a complete disappearance of infiltrative changes in the lungs, in 14 (70\%) patients - a significant decrease in their severity on the 10th day of therapy. Signs of inflammatory infiltration in the lungs were not detected in all patients on the 15th-21st (on the average $15.3 \pm 1.2$ ) day after the start of therapy. It is important to mention that side effects from clarithromycin-MB therapy were observed in 3 patients in the form of nausea and short-term loosening of stool in one patient. These phenomena were momentary and did not require correction and withdrawal of the drug.

Conclusions. Macrolide Clarithromycin-MB in parenteral form of application is a highly effective antibacterial drug for the treatment of severe NHP. Positive dynamics of clinical manifestations of the disease was observed on the 3rd day from the beginning of therapy.

Clarithromycin-MB has good therapeutic tolerability in patients with NHP. The identified side effects were momentary and did not require additional drug correction and drug withdrawal. Dosage regimen $(500 \mathrm{mg} 2$ times a day intravenously drip for 60 minutes for 7-10 days) allows maintaining the required concentration in the focus of inflammation, which affects the clinical and bacteriological efficiency of therapy.

\section{References}

1. Shikhnebiev DA, Modern approaches to antimicrobial therapy of community-acquired pneumonia (literature review). International Journal of Applied and Basic Research. 2014; 4: 101-104.

2. Protocol of good medical assistance We have a problem with non-hospital and nosocomial (hospital) pneumonia in older adults: etiology, pathogenesis, classification, diagnostics, antibacterial therapy. Order of the Ministry of Health of Ukraine No. 128 dated 19.03. 2007 p.

3. Feshchenko YuI, Golubovska OA, Goncharov KA, Dziublyk OYa, Dziublyk YaO, Dmitrichenko VV, Kapitan GB, Kliagin VYa, Mostovyi YuM, Mukhin OO, Nedlinska NM, Obertynska OV, Pertseva TO, Pylypenko MM, Simonov SS, Sukhin RYe, Shlapak IP, Yudina LV. Community-acquired pneumonia in adults: etiology, pathogenesis, classification, diagnosis, antibiotic therapy (draft clinical guidelines) Part II. Ukrainian pulmonological journal. 2013;1:5-21.

4. Antimicrobial Resistance, Electronic source: http://www.who.int/ drugresistance/en/

5. Sahm DF, Antimicrobial resistance trends among sinus isolates of Streptococcus pneumoniae in the United States (20012005). Otolaryngol. Head Neck Surg. 2007;- 136 (3):385-389.

6. Strachunsky HP, Kozlov SN, Macrolides in modern clinical practice. Clinical medicine. 2012;3:23-30.

7. Greenwood D, Antimicrobial Chemotherapy, Oxford.1995;4:43-49. 
8. Labro MT, Antibiotics as anti-inflammatory drugs. Current Opinion in Investigational Drugs. 2002.

9. Kohno SA, New macrolide, TE-031 (A-56268), in treatment of experimental Legionnais' disease. J. Antimicrob. Chemother.1989;24:397-405.

10. Takeda H, Long-term administration study on TE-031 (A-56268) in treatment of diffuse panbronchiolitis.1989;63:7178.

11. Gogos CA, Drosou E, Bassaris HP, Skoutelis A, Proversus anti-inflammatory cytokine profile in patients with severe sepsis: a marker for prognosis and future therapeutic options. J. Infect. Dis.2002;181:176-180.
12. Giamarellos-Bourboulis EJ, Pechère JC, Routsi C, Effect of clarithromycin in patients with sepsis and ventilatorassociated pneumonia. Clin. Infect. Dis.2008;46(8):11571164. doi: $10.1086 / 529439$.

13. Averyanov AV, Zykov KA, Clarithromycin in the treatment of exacerbations of chronic obstructive pulmonary disease. Ukr. pulmonol. magazine. 2009; 2: 48-52.

14. Norimichi A, Naoki I, Kazutaka M, Yutaro N, Hiroshi H. Effect of rifampicin and clarithromycin on the CYP3A activity in patients with Mycobacterium avium complex. J Thorac Dis.2019;11(9):3814-3821. DOI: 10.21037/jtd.2019.09.06.

\title{
КЛНІЧНА ЕФЕКТИВНІСТЬ КЛАРИТРОМЩИНУ-МБ В КОМПЛЕКСНІЙ ТЕРАПЇ ХВОРИХ НА НЕГОСПІТАЛЬНУ ПНЕВМОНІЮ
}

\author{
Лядова Т. І., Волобуєва О. В., Нартов П. В., Маланчук С. Г., Гололобова О. В., Козлов О. П., Касьян Н. В., \\ Гаміловска А. П., Шандер Т. А.
}

Пошта для листування: o.volobyeva @ karazin.ua

\begin{abstract}
Резюме: Проблема раиіональної антибіотикотерапії пневмонії залпиається однією з найбільш актуальних у сучасній медицині. Метою дослідження була оиінка клінічної ефективності та терапевтичної переносимості кларитроміиину для парентерального застосування у лікуванні хворих на негоспітальну пневмонію (НПГ). Матеріали та методи. Під нашим спостереженням знаходилися 20 паиієнтів: 12 чоловіків - (60\%), 8жінок - (40\%), середній вік хворих становив 46, 1 $\pm 17,6$ року. У всіх паміснтів спостерігалася клінічна симптоматика тяюского інфекиійного уражсення ниюних дихальних шляхів. У 73,0\% (15 хворих) зазначалося двобічне уражсення легень, у 27\% (5 хворих) - односторонне уражсення легеневої тканини. Кровохаркання відмічалося у 4 (20\%) паиієнтів. В комплексну терапію (дезінтоксикаиійні, муколітичні препарати, полівітаміни, метаболіки) 6 хвории на НП включали Кларитроміицн-МБ через 3 доби неефективної стартової терапії, 14 хворихна НПотримували кларитромічин-МБ відразу після надходження до стаиіонару. Препарат вводили внутрішньовенно крапельно трівалістю 60 хвилин в дозі 500 мг 2 рази на добу протягом 7-10 діб. Результати. Аналіз отриманих результатів терапії кларитромицином-МБ показав, що клінічний успіх був досягнутий у всіх паиієнтів. Позитивна динаміка клінічних показників відзначалася вже на 3-й день від початку антибактеріальної терапї кларитроміцином-МБ, що виражкалося в зниюсенні температури тіла, до 7-го дня лікування практично у всіх хворих температура нормалізувалася і тільки у 1 (5\%) хворого зберігалася субфебрильною. Також памієнти в ией період відзначали зменшення больового синдрому, у них знижувалися ознаки інтоксикаиії. За даними рентгенологічних досліджень на 10-й день терапії у 6 (30\%) хворих відзначалося повне зникнения інфільтративних змін в легенях, у 14 (70\%) хворих - значне зменшення їх виражкеності. У всіх хворих ознаки запальної інфільтрації в легенях не виявлялися на 15-24-й (в середньому 15,3 \pm 1,2) день після початку терапії. Висновки. Кларитроміиин-МБ має гарну терапевтичну переносимість, резжим дозування дозволяє підтримувати необхідну конщентрамію у вогничі запалення, щю впливає на клінічну і бактеріологічну ефективність терапії.
\end{abstract}

Ключові слова: негоспітальна пневмонія, макроліди, кларитроміцин, дихальна недостатність, лабораторна діагностика

\footnotetext{
Інформація про авторів

Лядова Тетяна Іванівна, д. мед. н., проф., зав. кафедри загальної та клінічної імунології та алергології медичного факультету Харківського національного університету імені В. Н. Каразіна, майдан Свободи, 6, Харків, Україна, 61022

e-mail: t.lyadova@karazin.ua

https://orcid.org/0000-0002-5892-2599

Волобуєва Ольга Вікторівна, к. мед. н., доц. кафедри загальної та клінічної імунології та алергології медичного факультету Харківського

національного університету імені В. Н. Каразіна,

майдан Свободи, 6, Харків, Україна, 61022

e-mail: o.volobyeva@karazin.ua https://orcid.org/0000-0002-5569-1748

Нартов Павло Вікторович, д. мед. н., проф. кафедри загальної та клінічної імунології та алергології медичного факультету Харківського національного університету імені В. Н. Каразіна, майдан Свободи, 6, Харків, Україна, 61022
}

e-mail:okia.mf@karazin.ua

Маланчук Світлана Генадївна, к. б. н., доц. кафедри загальної та клінічної імунології та алергології медичного факультету Харківського національного університету імені В. Н. Каразіна, майдан Свободи, 6, Харків, Україна 61022

e-mail: s.malanchuk@karazin.ua https://orcid.org/0000-0002-9376-3693

Гололобова Олеся Василівна, к. мед. н., доц. кафедри загальної та клінічної імунології та алергології медичного 
факультету Харківського національного університету імені В. Н. Каразіна, майдан Свободи, 6, Харків, Україна, 61022

e-mail: gololesya@ukr.net

https://orcid.org/0000-0002-1713-2988

Козлов Олександр Петрович, к. мед. н., доц. кафедри загальної та клінічної імунології та алергології медичного факультету Харківського національного університету імені В. Н. Каразіна, майдан Свободи, 6, Харків, Україна, 61022

e-mail:kozlov@karazin.ua https://orcid.org/0000-0003-0320-1505

Касьян Наталія Володимирівна, асистент кафедри загальної та клінічної імунології та алергології медичного факультету Харківського національного університету імені В.Н. Каразіна, майдан Свободи, 6, Харків, Україна, 61022

e-mail: n.kasyan@karazin.ua https://orcid.org/0000-0003-4267-7995

Гаміловська Алла Петрівна, асистент кафедри загальної та клінічної імунології та алергології медичного факультету Харківського національного університету імені В. Н. Каразіна, майдан Свободи, 6, Харків, Україна, 61022

e-mail: gamilovska@ karazin.ua https://orcid.org/0000-0002-6652-0952

Шандер Тетяна Анатолївна, асистент кафедри загальної та клінічної імунології та алергології медичного факультету Харківського національного університету імені В. Н. Каразіна, майдан Свободи, 6, Харків, Україна, 61022

e-mail: tanyashander@gmail.com

\title{
КЛИНИЧЕСКАЯ ЭФФЕКТИВНОСТЬ КЛАРИТРОМИЦИНА-МБ В КОМПЛЕКСНОЙ ТЕРАПИИ БОЛЬНЫХ НЕГОСПИТАЛЬНОЙ ПНЕВМОНИЕЙ
}

\author{
Лядова Т. И., Волобуева О. В., Нартов П.В., Маланчук С. Г., Гололобова О. В., Козлов А. П., \\ Касьян Н. В., Гамиловская А. П., Шандер Т. А.
}

Пошта для листування: o.volobyeva@karazin.ua

Резюме. Проблема рациональной антибактериальной терапии пневмонии остается одной из самых актуальных в современной медицине. Целью исследования была оценка клинической эффективности и терапевтической переносимости кларитромицина для парентерального применения в лечении больных негоспитальной пневмонией (НП). Материалы и методы. Под нашим наблюдением находились 20 пациентов: 12 мужчин - (60\%), 8 женщин - (40\%), средний возраст больных составил 46,1 1 17,6 года. У всех пациентов наблюдалась клиническая симптоматика тяжелого инфекиионного поражения нижних дыхательных путей. В 75,0\% (15 больных) отмечалось двустороннее поражение легких, в 27\% (5 больных) - односторонне поражения легочной ткани. Кровохарканье отмечалось у 4 (20\%) пациентов. $B$ комплексную терапию (дезинтоксикаиионные, муколитические препараты, поливитамины, метаболика) 6 больным НП включали Кларитромицин-МБ через 3 суток неэффективной стартовой терапии, 14 больных ЧП получали кларитромицин-МБ сразу после поступления в стачионар. Препарат вводили внутривенно капельно продолжительностью 60 минут в дозе 500 мг 2 раза в сутки в течение 7-10 суток. Результаты. Анализ полученных результатов терапии кларитромицином-МБ показал, что клинический успех был достигнут у всех пачиентов. Положительная динамика клинических показателей отмечалась уже на 3-й день от начала антибактериальной терапии кларитромицином-МБ, что выражалось 8 снижении температуры тела до 7-го дня лечения и практически у всех больных температура нормализовалась и только у 1 (5\%) больного сохранялась субфебрильной. Также пациенть в этот период отмечали уменьшение болевого синдрома, у них снижались признаки интоксикации. По данным рентгенологических исследований на 10-й день терапии у 6 (30\%) больных отмечалось полное исчезновение инфильтративных изменений в легких, у 14 (70\%) больных - значительное уменьшение их выраженности. У всех больных признаки воспалительной инфильтрации в легких нивелировались на 15 24-й (в среднем 15,3 \pm 1,2) день после начала терапии. Выводы. Кларитромицин-МБ имеет хоромую терапевтическую переносимость, режим дозирования позволяет поддерживать необходимую кониентрацию в очаге воспаления, влияет на клиническую и бактериологическую эффективность терапии.

Ключевые слова: негоспитальная пневмония, макролиды, кларитромицин, дыхательная недостаточность, лабораторная диагностика

\footnotetext{
Информация об авторах

Лядова Татьяна Ивановна, д. мед. н., проф., зав. кафедры общей и клинической иммунологии и аллергологии медицинского факультета Харьковского национального университета имени В. Н. Каразина, пл. Свободы, 6, Харьков, Украина, 61022 e-mail: t.lyadova@karazin.ua
}

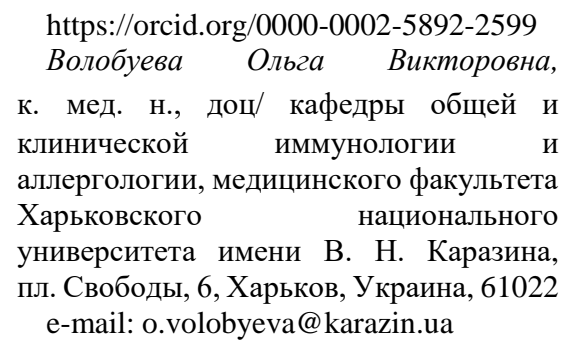

https://orcid.org/0000-0002-5569-1748

Нартов Павел Викторович, д. мед. н., проф. кафедры общей и клинической иммунологии и аллергологии медицинского факультета Харьковского национального университета имени В. Н. Каразина, пл. Свободы, 6, Харьков, Украина, 61022

e-mail:okia.mf@karazin.ua 
Actual problems of modern medicine. Issue 6, 2020

Маланчук Светлана Геннадиевна, к. б. н., доц. кафедры общей и клинической иммунологии и аллергологии, медицинского факультета Харьковского национального университета имени В. Н. Каразина, пл. Свободы, 6, Харьков, Украина, 61022 e-mail: s.malanchuk@karazin.ua https://orcid.org/0000-0002-9376-3693

Гололобова Олеся Васильевна, к. мед. н., доц. кафедры общей и клинической иммунологии и аллергологии медицинского факультета Харьковского национального университета имени В. Н. Каразина, пл Свободы, 6, г. Харьков, Украина, 61022 e-mail: ololesya@ukr.net https://orcid.org/0000-0002-1713-2988 Козлов Александр Петрович, к. мед. н., доц. кафедры общей и клинической иммунологии и аллергологии медицинского факультета Харьковского национального университета имени В. Н. Каразина пл. Свободы, 6, Харьков, Украина, 61022 e-mail:kozlov@karazin.ua https://orcid.org/0000-0003-0320-1505

Касьян Наталья Владимировна, ассистент кафедры общей и клинической иммунологии и аллергологии медицинского факультета Харьковского национального университета имени В. Н. Каразина, пл. Свободы, 6, Харьков, Украина, 61022 e-mail: n.kasyan@karazin.ua https://orcid.org/0000-0003-4267-7995 Гамиловская Алла Петровна,
ассистент кафедры общей и клинической иммунологии и аллергологии медицинского факультета Харьковского национального университета имени В. Н. Каразина пл. Свободы, 6, Харьков, Украина, 61022 e-mail: gamilovska@ karazin.ua https://orcid.org/0000-0002-6652-0952
Шандер Татьяна Анатольевна, ассистент кафедры общей и клинической иммунологии и аллергологии медицинского факультета Харьковского национального университета имени В. Н. Каразина, пл. Свободы, 6, Харьков, Украина, 61022 e-mail: tanyashander@gmail.com

Conflicts of interest: author has no conflict of interest to declare.

Конфлікт інтересів: відсутній.

Конфликт интересов: отсутствует. 